\title{
Use of induced abortion for birth control by mothers in Iraq
}

Hajir Al-Ridhwany, ${ }^{1}$ Asma Aljawadi ${ }^{2}$ and Muthanna Abduljawad ${ }^{3}$

${ }^{1}$ Department of Public Health Care, Nineveh Health Directorate, Erbil, Iraq (Correspondence to: Hajir H. Al-Ridhwany: hajirhusam@gmail.com). ${ }^{2}$ Department of Family and Community Medicine, College of Medicine, University of Mosul, Mosul, Iraq. ${ }^{3} \mathrm{Al}-\mathrm{Salam}$ Teaching Hospital, Nineveh Health Directorate, Erbil, Iraq.

\begin{abstract}
Background: Induced abortion is a traditional method of birth control and it can indicate unmet maternal reproductive needs. Little is known about the use of induced abortion by married women in Iraq.

Aims: This cross-sectional study aimed to explore whether induced abortion is used for birth control by married women in Mosul, and to determine the sociodemographic and family characteristics associated with its use.

Methods: Multistage stratified sampling was used to recruit 1302 married women of child-bearing age (15-49 years) attending primary health care centres in Mosul. Women were interviewed using a validated questionnaire between April 2011 and 31 January 2012. Data collected included: use of induced abortion and method, social and family background, and contraceptive use. The $\chi^{2}$-test was used to assess the association of sociodemographic and cultural factors with the induced abortion.

Results: Of the 1302 women, $13.5 \%$ had tried to induce an abortion at some time, by undertaking heavy physical activities $(66.2 \%)$ or using of herbal remedies $(22.2 \%)$ or pharmacological preparations (17.6\%). The prevalence of reported induced abortion was significantly lower among women using contraceptives, older women, those with a higher education, working women, suburban and rural residents, those living in extended families, and women in consanguineous marriages and non-polygynous marriages $(P<0.05)$.

Conclusions: Over $10 \%$ of the married women had induced abortion to control births. Health education is recommended to encourage contraceptive use.

Keywords: Abortion, induced; prevalence, birth control, Iraq

Citation: Al-Ridhwany H; Aljawadi A; Abduljawad M. Use of induced abortion for birth control by mothers in Iraq. East Mediterr Health J. 2018;24(7):644-652. https://doi.org/10.26719/2018.24.7.644

Received: 15/08/16; accepted: 11/07/17

Copyright ( ) World Health Organization (WHO) 2018. Some rights reserved. This work is available under the CC BY-NC-SA 3.0 IGO license (https:// creativecommons.org/licenses/by-nc-sa/3.o/igo).
\end{abstract}

\section{Introduction}

Women can face many challenges in relation to their reproductive health, including abortion, maternal mortality, poor availability of information and family planning services, and sexually transmitted infections (1).

Induced abortion is one of the traditional methods of birth control and its prevalence can be used as an indicator for unmet maternal reproductive needs $(2,3)$. Even where family planning methods are available, a woman may not use them because of financial constraints, personal beliefs, opposition from family members, or concerns about the perceived adverse effects on health or future fertility (4). Induced abortion is defined as the intentional termination of a pregnancy before the fetus can live independently. It may be elective (based on a woman's personal choice) or therapeutic (to preserve the health or save the life of a pregnant woman). It may also be unsafe. The World Health Organization (WHO) defines unsafe abortion as a procedure for terminating a pregnancy that is performed by an individual lacking the necessary skills, or in an environment that does not conform to minimal medical standards, or both (5).

Little is known about the use of induced abortion by married women in Iraq. The present study therefore aimed to determine whether induced abortion is used as a method of birth control among mothers in Mosul, northern Iraq and the sociodemographic and family factors associated with such behaviour.

\section{Methods}

\section{Study design}

A cross-sectional design was used.

\section{Sample size and selection}

The required sample size (n) was estimated by the Daniel equation (6): $\mathrm{n}=[\{\mathrm{Z}(1-\alpha) 2 \times \mathrm{pq} / \mathrm{d} 2\} \times 2]+5 \%$, where: $\alpha=$ $0.05, Z=1.96$, p (proportion of married women of childbearing age $)=14 \%(7), q=0.86 ; d=0.03$; design effect $=2(8)$ and contingency error $=5 \%$ (6). Therefore, the minimum sample size required for the study with $95 \%$ confidence interval and 0.03 width, was 1231 married women of child-bearing age (15-49 years). We interviewed 1302 women. Distribution of the estimated sample was weighted taking into consideration the population size and proportion of married women of child-bearing age in each catchment area ( $14 \%$ of the total population) (see Appendix available online).

A multistage stratified sampling method was used. 
For the purposes of this research, Mosul was divided into four areas: north-east, north-west, south-east and south-west. Each area was stratified into 3 social strata (urban, suburban and rural) according to their closeness to the city centre of Mosul. Then, 20 primary health care centres (PHCCs) $-70 \%$ of all health centres in Mosulwere non-randomly selected according to population size and proportion of women of child-bearing age (1549 years) in each catchment area (7) (Figure 1). Finally, a convenience sample of eligible women was selected. Women were approached on entry to the examination room, and eligible mothers who consented to be included in the study were interviewed. The inclusion criteria were: currently married, woman of child-bearing age (1549 years) and attending one of the selected health centres.

A specially designed interview questionnaire was developed which enquired about: experience of induced abortion as a means of birth control, and sociodemographic and family characteristics. The questionnaire was validated using the Angoff method (9). We recruited 11 experts to judge the coverage, clarity and reality of the questionnaire. They assessed its validity in the 3 areas as $85.0 \%, 85.5 \%$ and $80.9 \%$ respectively. To assess the questionnaire reliability, a pilot study was conducted in Al-Arabi health centre, one of the selected centres, among 20 women who met the inclusion criteria; they were chosen consecutively during their visits to the antenatal care unit within the centre: reliability was $87.2 \%$, and intra-observer and inter-observer variation were $86.8 \%$ and $82.9 \%$ respectively.

\section{Data collection}

It took 10 months (1 April 2011 - 31 January 2012) to collect all the required data. The biggest problem in collecting the data was asking the women about their sociodemographic characteristics, especially the young women, mainly because of the volatile security situation in Mosul. People in Mosul have witnessed many criminal events since 2003 (killings, kidnappings and blackmail) which were still occurring during the study period. Thus, people are very apprehensive about talking with strangers, particualrly about address, husband's occupation, economic status, children, and many other personal details. Revealing such information is considered risky and might threaten the whole family. Wives, who have the weakest position in the family, are more likely to be blamed for any leaked information. As a result, the mothers were very cautious at the beginning of the interview. However, this problem was solved by good communication and explaining the aim of the study. Mothers were allowed first to talk freely about their pregnancies and children. Then, they answered the open-ended questions on the questionnaire and lastly, when they felt safe, they started to discuss their sociodemographic backgrounds.

All the required data, including husband's characteristics, were obtained by interviewing the eligible mothers. Husband's occupation was considered an important item because it can determine the social class of the family according to the general occupational classification in England and Wales, as described by Al-Youzbaki (10).

\section{Statistical analysis}

The study aimed to determine the prevalence of induced abortion as a means of birth control within the studied sample. The association of some sociodemographic and cultural factors with the induced abortion was examined using the chi-squared test. A P-value $\leq 0.05$ was considered statistically significant. Odds ratios (OR) and 95\% confidence intervals (CI) were calculated (6).

\section{Ethical considerations}

The study received ethical approval from the Nineveh Health Directorate in Mosul. The purpose of the study

Figu re 1 Map of Mosul city, northern Iraq, showing the geographical division of the city by the Tigris River and Nineveh Street into 4 quarters and the distribution of the 20 primary health care centres (red stars) included

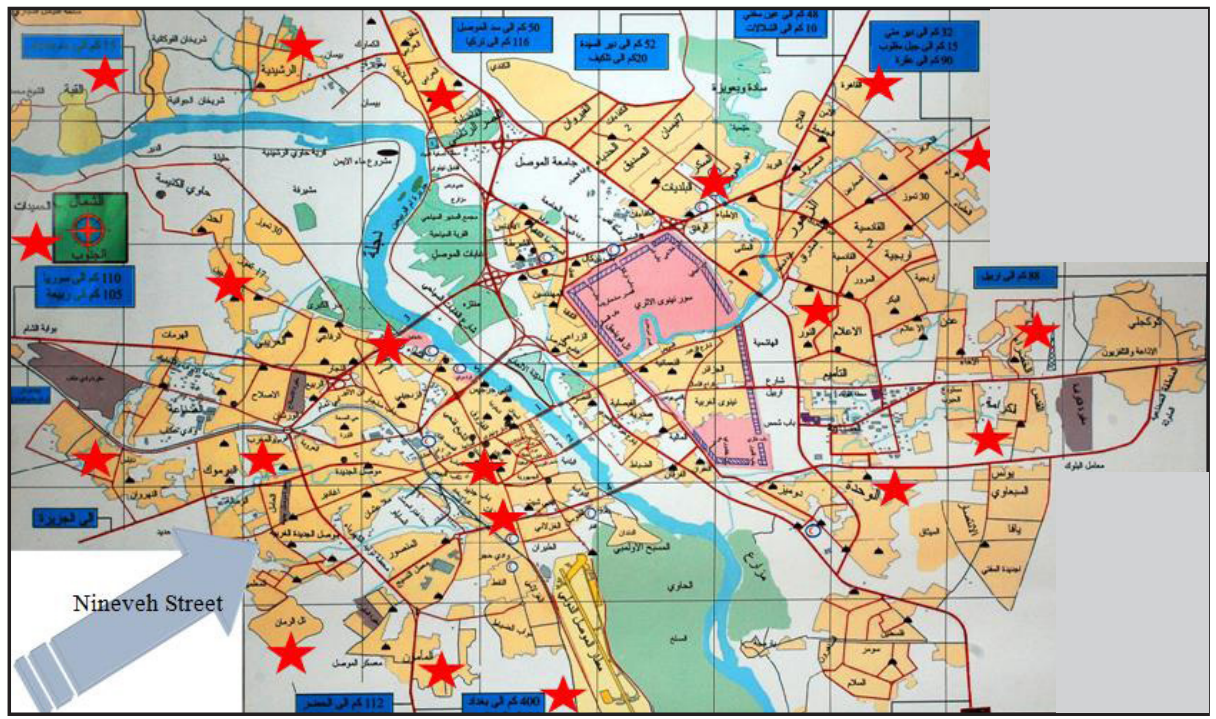




\begin{tabular}{|c|c|c|c|c|c|}
\hline \multirow{3}{*}{$\begin{array}{l}\text { Sociodemographic } \\
\text { characteristics }\end{array}$} & \multicolumn{2}{|c|}{ Induced abortion } & \multirow{3}{*}{ 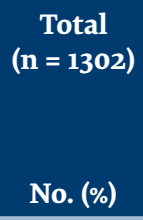 } & \multirow[t]{3}{*}{ OR $(95 \% C I)^{a}$} & \multirow[t]{3}{*}{ P-value } \\
\hline & $\begin{array}{c}\text { Yes } \\
(\mathrm{n}=176)\end{array}$ & $\begin{array}{c}\text { No } \\
(\mathrm{n}=1126)\end{array}$ & & & \\
\hline & No. (\%) & No. (\%) & & & \\
\hline \multicolumn{6}{|l|}{ Religion } \\
\hline Muslim & $154(12.6)$ & $1069(87.4)$ & $1223(93.9)$ & $0.4(0.2-0.6)$ & $<0.001$ \\
\hline Christian & $22(27.8)$ & $57(72.2)$ & $79(6.1)$ & & \\
\hline \multicolumn{6}{|l|}{ Ethnicity } \\
\hline Arab & $163(15.0)$ & $927(85.0)$ & $1090(83.7)$ & $2.7(1.5-5.1)$ & 0.001 \\
\hline Kurd & $4(4.2)$ & $91(95.8)$ & $95(7.3)$ & $0.3(0.1-0.8)$ & 0.006 \\
\hline Turkmen & $5(7.9)$ & $58(92.1)$ & $63(4.9)$ & $0.4(0.1-0.9)$ & 0.02 \\
\hline Shabak & $4(7.4)$ & $50(92.6)$ & $54(4.1)$ & $0.5(0.2-1.5)$ & 0.2 \\
\hline \multicolumn{6}{|l|}{ Residence } \\
\hline Urban & $134(19.6)$ & $548(80.4)$ & $682(52.4)$ & $3.4(2.3-4.8)$ & $<0.001$ \\
\hline Suburban and rural & $42(6.8)$ & $578(93.2)$ & $620(47.6)$ & & \\
\hline \multicolumn{6}{|l|}{ Urbanization $^{b}$} \\
\hline Present & $16(8.2)$ & $179(91.8)$ & $195(15.0)$ & $0.5(0.3-0.9)$ & 0.02 \\
\hline Absent & $160(14.5)$ & $947(85.5)$ & $1107(85.5)$ & & \\
\hline \multicolumn{6}{|l|}{ Social class ${ }^{c}$} \\
\hline 1st and 2nd & $6(12.5)$ & $42(87.5)$ & $48(3.7)$ & $0.9(0.3-2.3)$ & 0.8 \\
\hline 3 rd & $91(14.5)$ & $537(85.5)$ & $628(48.2)$ & $1.2(0.8-1.6)$ & 0.3 \\
\hline 4th and 5th & $56(10.9)$ & $458(89.1)$ & $514(39.5)$ & $0.7(0.5-0.9)$ & 0.02 \\
\hline Unemployed & $23(20.5)$ & $89(79.5)$ & $112(8.6)$ & $1.8(1.0-2.9)$ & 0.02 \\
\hline
\end{tabular}

${ }^{a}$ For ethnicity and social class ORs ( $95 \%$ CIs), each group was compared with the sum of the other 3 groups.

${ }^{b}$ Moved from rural areas to an urban area in the past 10 years.

'Based on husband's occupation: 1st and 2nd = professional/semi-professional occupations; 3 rd = non-manual skilled occupations; 4th and 5th = partly skilled/unskilled occupations. $\mathrm{OR}=$ odds ratio, $\mathrm{CI}=$ confidence interval.

was explained to the women and their verbal consent was obtained before the interviews. It was made clear to them that they did not have to participate and they could withdraw at any time, and that this would not affect their care at the health centre.

\section{Results}

A total of 1302 mothers who met the inclusion criteria were interviewed; only 2 women declined to participate. The mean age and standard deviation (SD) of the sample was 30.0 (SD 7.7) years; 7.4\% were teenagers. The majority of the women $(70.3 \%$ ) were $20-39$ years old and $12.3 \%$ were older. More than half of the women $(52.4 \%)$ were urban residents. Most of the women (93.9\%) were Muslims, and $83.7 \%$ were Arabs, $7.3 \%$ Kurds, $4.8 \%$ Turkmen and $4.1 \%$ Shabaks. Almost half of the women (48.8\%) were illiterate.

Of the 1302 women, 176 (13.5\%) had induced an abortion at some time in their reproductive life: 106 (60.2\%) had done so by undertaking heavy physical activities, 39 (22.2\%) had used herbal remedies and 31 (17.6\%) had used pharmacological preparations.

The association of different sociodemographic characteristics with induced abortion is shown in Table 1. The reported prevalence of induced abortion was significantly lower in Muslim women than Christian
(12.6\% versus $27.8 \%$ ) (OR 0.4, 95\% CI: $0.2-0.6, \mathrm{P}<0.001$ ). The prevalence of induced abortion was about 2 to 3 times higher in Arab women (15.0\%) than Kurds and Turkmen (4.2\% and 7.9\% respectively) (OR 0.3, 95\% CI: 0.1$0.8, P=0.006$ and OR 0.4, 95\% CI: 0.1-0.9, $P=0.02)$. More urban women (19.6\%) had tried inducing an abortion than suburban and rural women (6.8\%) (OR 3.4, 95\% CI: 2.3-4.8, $P<0.001$ ), but fewer urbanized mothers (those who had moved from rural areas to urban settings in the past 10 years) had tried to induce an abortion (OR 0.5, 95\% CI: $0.3-0.9, P=0.02$ ).

Significantly more mothers with unemployed husbands had tried to induce abortion (20.5\%) than mothers with employed husbands (OR 1.8, 95\% CI: 1.0-2.9, $P=0.02)$. Among the latter, the lowest prevalence (10.9\%) was reported by mothers whose husbands had partly skilled/unskilled occupations (OR 0.7, 95\% CI: 0.5-0.9, P = 0.02).

Table 2 shows prevalence of induced abortion according to family characteristics. The reported prevalence of induced abortion was significantly higher among women living in a nuclear family (18.7\%) than those living in an extended family (9.9\%) (OR 2.1, 95\% CI: 1.5-2.9, $P<0.001$ ), and in women living in polygynous families (marriage of a man to more than one woman at a time) 
(28.4\% versus $12.6 \%$ ) (OR 2.8, 95\% CI: $1.7-4.4, P<0.001)$. The prevalence of induced abortion was significantly lower in women in a consanguineous marriage (10.3\% versus 19.6\%) (OR 0.5, 95\% CI: 0.3-0.7, P < 0.001).

Table 3 shows the prevalence of induced abortion according to the woman's and her husband's characteristics. Mothers under 30 years of age were significantly more likely to have tried to induce an abortion (16.3\%) than older women (10.8\%0 (OR 1.6, 95\% CI: 1.1-2.2, $P=0.004)$. Induced abortion was significantly less likely to be reported by mothers with less than 12 years of schooling ( $12.6 \%$ versus $27.7 \%$ of higher educated women) (OR 0.4, 95\% CI: 0.2-0.6, $P<0.001$ ) and housewives $(12.1 \%$ versus $30.3 \%$ of working women) (OR 0.3, 95\% CI: 0.2-0.5, $P<0.001)$. Moreover, contraceptives use significantly reduced the prevalence of induced abortion (6.9\% versus $20.7 \%$ of non-users) (OR 0.3, 95\% CI: $0.2-0.4, P<0.001$ ). Women whose husbands were under 30 years of age were significantly less likely to have tried to induce an abortion (5.6\% versus $16.1 \%$ with older husbands) (OR $0.3,95 \%$ CI: $0.2-0.4, P<0.001)$. The age of the woman and her husband at marriage, the age of the woman at first pregnancy, and the husband's education were not significantly associated with induced abortion.

\section{Discussion}

Obtaining information about the practice of induced abortion is challenging because of the culture of silence that surrounds the topic. According to the finding of our study, $13.5 \%$ of the mothers in Mosul had tried to induce abortion intentionally to control their births at some point in their reproductive life. The real prevalence of induced abortion in the community may be higher. The possibility of underestimation may be due to recall bias, which usually accompanies a cross-sectional study design. It may also be a result of non-differential misclassification which might be expected when researching such a sensitive issue in our setting: mothers might have answered the question about inducing an abortion by giving a socially acceptable but inaccurate reply. This type of bias tends towards the null hypothesis which can result in an underestimation of the true situation (11).

Although induced abortion has been legal in the United States of America since 1973, it is not generally considered permissible by many religions and societies (12). Under the Iraqi general principles of criminal law, as stated in article 63 of the Penal Code (13), the abortion law explicitly prohibits the performance of abortions, but implies several exceptions in cases of necessity. Induced abortion is allowed in Iraq to preserve the life and health of the pregnant woman and for reasons of fetal abnormality. Iraqi law also allows abortion in cases of incest and rape. Islamic teachings encourage Muslims to reproduce and forbids fetal killing except when the pregnancy is proved to be a high risk to the pregnant woman. In such cases, induced abortion may be allowed (14).

This may be the first time such a sensitive topic had been addressed in a study setting. As a result, there are no available data on the practice of induced abortion as a method birth control in Iraq. However, the estimated prevalence is almost 3 times that reported by a nationally representative survey in Syria in 2006 (15) which reported that $4 \%$ of married women ages $15-49$ years had had at least one abortion; the authors noted that the figure was likely to be an underestimation because abortion is also banned in the country.

Most of the induced abortions in the present study were attempted by heavy physical efforts and to a lesser extent by the use of some herbal and pharmaceutical substances. None of the women reported surgical intervention for terminating the pregnancy. However, this does not mean that surgical intervention did not occur and that unsafe abortion did not happen. However, this is against the law and the religion so it is unlikely any women would admit to this.

\begin{tabular}{|c|c|c|c|c|c|}
\hline \multirow[t]{3}{*}{ Family characteristic } & \multicolumn{2}{|c|}{ Induced abortion } & \multirow{2}{*}{$\begin{array}{c}\text { Total } \\
(\mathrm{n}=1302)\end{array}$} & \multirow[t]{3}{*}{ OR $(95 \% \mathrm{CI}) \mathrm{a}$} & \multirow[t]{3}{*}{ P-value } \\
\hline & $\begin{array}{c}\text { Yes } \\
(\mathbf{n}=176)\end{array}$ & $\begin{array}{c}\text { No } \\
(\mathrm{n}=1126)\end{array}$ & & & \\
\hline & No. (\%) & No. (\%) & No. (\%) & & \\
\hline \multicolumn{6}{|l|}{ Family structure } \\
\hline Nuclear & $101(18.7)$ & $440(81.3)$ & $541(41.6)$ & \multirow[t]{2}{*}{$2.1(1.5-2.9)$} & \multirow[t]{2}{*}{$<0.001$} \\
\hline Extended & $75(9.9)$ & $686(90.1)$ & $761(58.4)$ & & \\
\hline \multicolumn{6}{|l|}{ Consanguineous marriage } \\
\hline Yes & $88(10.3)$ & $764(89.7)$ & $852(65.4)$ & \multirow[t]{2}{*}{$0.5(0.3-0.7)$} & \multirow[t]{2}{*}{$<0.001$} \\
\hline No & $88(19.6)$ & $362(80.4)$ & $450(34.6)$ & & \\
\hline \multicolumn{6}{|l|}{ Polygyny } \\
\hline Yes & $27(28.4)$ & $68(71.6)$ & $95(7.3)$ & \multirow[t]{2}{*}{$2.8(1.7-4.4)$} & \multirow[t]{2}{*}{$<0.001$} \\
\hline No & 152 (12.6) & $1055(87.4)$ & $1207(92.7)$ & & \\
\hline
\end{tabular}

$\mathrm{OR}=$ odd s ratio, $\mathrm{CI}=$ confidence interval. 
Table 3 Association of induced abortion with personal characteristics of the woman and her husband

\begin{tabular}{|c|c|c|c|c|c|}
\hline \multirow[t]{3}{*}{ Personal characteristics } & \multicolumn{2}{|c|}{ Induced abortion } & \multirow{2}{*}{$\begin{array}{c}\text { Total } \\
(\mathrm{n}=\mathbf{1 3 0 2})\end{array}$} & \multirow{3}{*}{ OR $(95 \% \mathrm{CI}) \mathrm{a}$} & \multirow[t]{3}{*}{ P-value } \\
\hline & $\begin{array}{c}\text { Yes } \\
(n=176\end{array}$ & $\begin{array}{c}\text { No } \\
(n=1126)\end{array}$ & & & \\
\hline & No. (\%) & No. (\%) & No. $(\%)$ & & \\
\hline \multicolumn{6}{|l|}{ Woman's age (years) } \\
\hline$<30$ & $105(16.3)$ & $540(83.7)$ & $645(49.5)$ & $1.6(1.1-2.2)$ & 0.004 \\
\hline$\geq 30$ & $71(10.8)$ & $586(89.2)$ & $657(50.5)$ & & \\
\hline \multicolumn{6}{|l|}{$\begin{array}{l}\text { Woman's education } \\
\text { (years of schooling) }\end{array}$} \\
\hline$<12$ & $153(12.6)$ & $1066(87.4)$ & $1219(93.6)$ & $0.4(0.2-0.6)$ & $<0.001$ \\
\hline$\geq 12$ & $23(27.7)$ & $60(72.3)$ & $83(6.4)$ & & \\
\hline \multicolumn{6}{|l|}{ Woman's occupation } \\
\hline Housewife & $146(12.1)$ & $1057(87.9)$ & $1203(92.4)$ & $0.3(0.2-0.5)$ & $<0.001$ \\
\hline Working & $30(30.3)$ & $69(69.7)$ & $99(7.6)$ & & \\
\hline \multicolumn{6}{|l|}{$\begin{array}{l}\text { Woman's age at } \\
\text { marriage (years) }\end{array}$} \\
\hline$<20$ & $103(12.6)$ & $713(87.4)$ & $816(62.7)$ & $0.8(0.6-1.1)$ & 0.2 \\
\hline$\geq 20$ & $73(15.0)$ & $413(85.0)$ & $486(37.3)$ & & \\
\hline \multicolumn{6}{|l|}{$\begin{array}{l}\text { Woman's age at first } \\
\text { pregnancy (years) }\end{array}$} \\
\hline$<20$ & $100(13.6)$ & $635(86.4)$ & $735(56.5)$ & $1.0(0.7-1.4)$ & 0.9 \\
\hline$\geq 20$ & $76(13.4)$ & $491(86.6)$ & $567(43.5)$ & & \\
\hline \multicolumn{6}{|l|}{ Contraceptive use } \\
\hline Yes & $47(6.9)$ & $631(93.1)$ & $678(52.1)$ & $0.3(0.2-0.4)$ & $<0.001$ \\
\hline No & $129(20.7)$ & $495(79.3)$ & $624(47.9)$ & & \\
\hline \multicolumn{6}{|l|}{ Husband's age (years) } \\
\hline$<30$ & $18(5.6)$ & $302(94.4)$ & $320(24.6)$ & $0.3(0.2-0.5)$ & $<0.001$ \\
\hline$\geq 30$ & $158(16.1)$ & $824(83.9)$ & $982(75.4)$ & & \\
\hline \multicolumn{6}{|l|}{$\begin{array}{l}\text { Husband's age at marriage } \\
\text { (years) }\end{array}$} \\
\hline$<25$ & $73(13.6)$ & $464(86.4)$ & $537(41.2)$ & $1.0(0.7-1.4)$ & 0.9 \\
\hline$\geq 25$ & $103(13.5)$ & $662(86.5)$ & $765(58.8)$ & & \\
\hline \multicolumn{6}{|l|}{$\begin{array}{l}\text { Husband's education (years } \\
\text { of schooling) }\end{array}$} \\
\hline$<12$ & $150(14.4)$ & $895(85.6)$ & $1045(80.3)$ & $1.3(0.9-2.0)$ & 0.2 \\
\hline$\geq 12$ & $26(10.1)$ & 231 (89.9) & $257(19.7)$ & & \\
\hline
\end{tabular}

$\mathrm{OR}=$ odds ratio; $\mathrm{CI}=$ confidence interval.

According to the data published by the Population Reference Bureau (16), 1 in 4 pregnancies in the Middle East and North Africa region are unintended; they were either wanting to have a child later or not wanting any more children. Many women with unintended pregnancies resort to clandestine abortions that are not safe. The annual worldwide abortion rate in 2010-2014 was 35 per 1000 women aged 15-44 years; 27 per 1000 women in the developed regions and 37 per 1000 women in the developing world (17). During 2010-2014, 45\% of abortions were considered to be unsafe, with the Africa and Latin America having the higheset prevalence of insafe abortions (about 76\% each) (18).

Our study clearly shows that the lower the prevalence of contraceptive use, the higher the prevalence of induced abortion $(P<0.001)$. The prevalence of induced abortion as a birth control method was $20.7 \%$ among women who did not use contraceptives versus $6.9 \%$ among women who did. However, only just over half of the women were using a contraceptive method at the time of data collection. A cross-sectional study in Mosul in 2008 found that only $40.2 \%$ of mothers had their family planning needs met (women are said to have met their need for family planning when they use any method of contraception to delay or stop their next birth) (19). Yet, the same study reported that $20.2 \%$ of mothers were prohibited from using contraceptives and were described as having unmet needs. A later study in 2010 in Mosul 
found a higher prevalence of contraceptive use (50.4\%) among mothers of child-bearing age (20). However, both studies were based on health institutions. A communitybased survey in Iraq in 2006 reported that $33 \%$ of married women at the national level were using a family planning method, but the percentage was lower in Nineveh governorate (21.8\%) (21).

In the Islamic Republic of Iran in 2008 the abortion rate was reported to be 0.26 abortions per married woman (22), but it varied between provinces. The authors stated that the Islamic Republic of Iran, as other areas all over the world, showed a negative correlation between the use of contraceptives and the abortion rate: a lower rate of abortion was reported in areas that had higher rates of contraceptive use. Similarly, data from Tunisia and Turkey $(14,17)$ suggest that abortion rates have declined as family planning programmes have expanded. In Turkey, the rate of abortion dropped from $18 \%$ of pregnancies in 1993 to $11 \%$ in 2003 . At the same time, the percentage of married women using modern contraception increased from $34 \%$ to $42 \%$ during that period (16).

\section{Limitations}

In order to achieve the aims of the present study, a cross-sectional study design was used. Among the many advantage of this design is that it is relatively quick, easy to perform and comparatively less expensive. It also useful for measuring a current event and so can be helpful in the planning required health services (11). Furthermore, a cross-sectional study design has a long tradition in sociology and forms the general methodology of sociological researches (10). However, no cross-sectional study is free of recall biases which may alter the conclusions of a study (11). In our study, the questionnaire used was constructed to minimize such bias. The other important problem with cross-sectional studies is selection bias. Nonetheless, we selected our sample from women attending health institutions; such participants are not only more accessible but also more cooperative with investigators than persons in the community, particularly in discussing such an issue. In addition, a similar sample is more often associated with selection bias (23). However, in our study, efforts were made to select a representative sample by using a multistage stratified sampling technique so as to include all social strata distributed in urban, periurban and rural settings.

\section{Conclusion}

Induced abortion is still used for controlling birth by $13.5 \%$ of mothers in Mosul. This was significantly negatively associated with contraceptive use; women who used contraceptives were less likely to have reported an induced abortion. Health education is recommended to highlight the risks of induced abortion and to encourage contraceptive use. Health information can be introduced within high-school curricula in line with the customs and religious teachings of the local community. In addition, appropriate human resources are needed to make family planning programmes more acceptable and accessible.

\section{Acknowledgements}

We would like to thank the Nineveh Health Directorate for allowing us to conduct this study. We also thank Mosul University, College of Medicine, Department of Family and Community Medicine for their support and advice. Finally, we especially thank the study participants for their willingness to take part in this study

Funding: None.

Competing interests: None declared.

\section{L'avortement provoqué en tant que méthode contraceptive des mères en Iraq Résumé}

Contexte : L'avortement provoqué est une pratique traditionnellement adoptée comme méthode contraceptive et il peut indiquer des besoins non satisfaits en matière de reproduction chez les mères. Le recours à l'avortement provoqué chez les femmes mariées en Iraq reste un sujet méconnu.

Objectifs : La présente étude transversale avait pour objectif de rechercher si les femmes mariées résidant à Mossoul avaient recours à l'avortement provoqué en tant que méthode contraceptive et de déterminer les caractéristiques sociodémographiques et familiales liées à son utilisation.

Méthodes : L'échantillonnage stratifié à plusieurs degrés a été utilisé pour recruter 1302 femmes mariées en âge de procréer (15-49 ans) qui consultaient dans des établissements de soins de santé primaires à Mossoul. Les femmes ont été interrogées entre le mois d'avril 2011 et le 31 janvier 2012 à l'aide d'un questionnaire validé. Les données recueillies comprenaient le recours à l'avortement provoqué et la méthode utilisée, le contexte social et familial et l'utilisation de contraceptifs. Le test du $\chi^{2}$ a été utilisé pour évaluer l'association entre les facteurs sociodémographiques et culturels et l'avortement provoqué.

Résultats : Sur les 1302 femmes, $13,5 \%$ avaient tenté de déclencher un avortement provoqué au moins une fois via des activités physiques lourdes $(66,2 \%)$, l'administration de remèdes à base de plantes $(22,2 \%)$ ou des préparations pharmacologiques (17,6\%). La prévalence des avortements provoqués déclarés était significativement moindre parmi 
les femmes qui utilisaient des contraceptifs, les femmes plus âgées, celles qui étaient dotées d'un niveau d'éducation supérieur, les femmes actives, les femmes vivant en banlieue et en zone rurale, les femmes vivant au sein de familles élargies et celles vivant au sein d'un mariage consanguin ou non-polygyne $(p<0,05)$.

Conclusions: Plus de $10 \%$ des femmes mariées avaient eu recours à l'avortement provoqué comme moyen de contraception. L'éducation en matière de santé est recommandée afin d'encourager l'utilisation de contraceptifs.

$$
\begin{aligned}
& \text { الإجهاض المتعمَّد لدى الأمهات بقصد تنظيم النسل في العراق }
\end{aligned}
$$

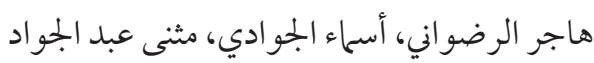

الخلفية: يعتبر الإجهاض المتعمَّد من الطرق التقليدية لتنظيم النسل، ويمكن أن يشير إلى مقدار الاحتياجات الإنجابية غير الملباة. و المعلومات قليلة

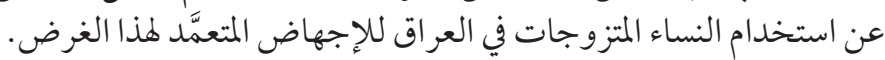

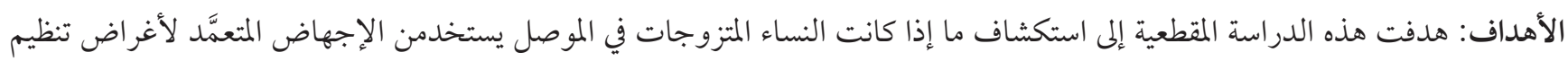

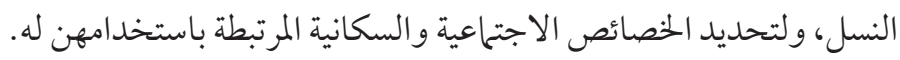

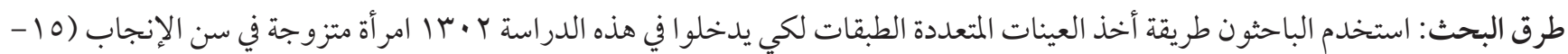

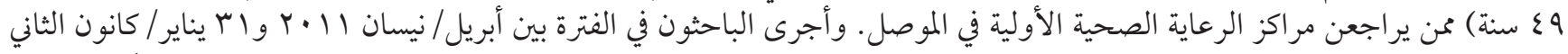

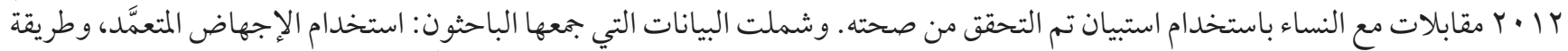

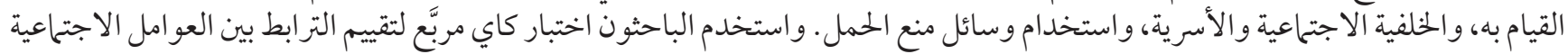
و السكانية والثقافية والإجهاض المتعمَّد.

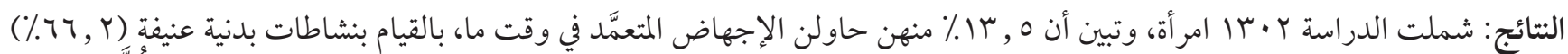

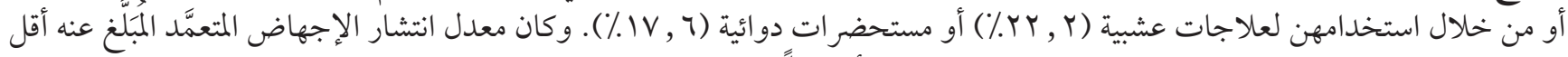

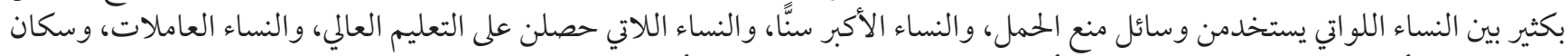

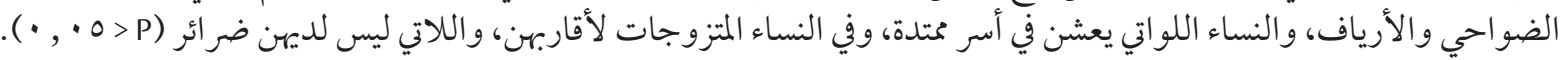

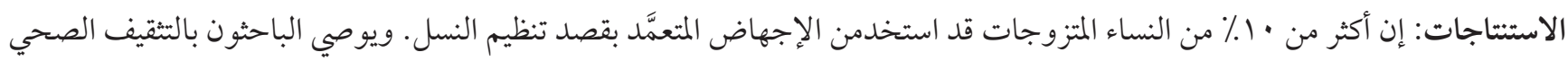
لتشجيع استخدام وسائل منع الحمل.

\section{References}

1. Maternal mortality and morbidity background paper. Inaugural Conference on Global Health, Gender and Human Rights. March 2012.

2. Miller G, Valente Ch. Population policy: abortion and modern contraception are substitutes. Demography. 2016 Aug;53(4):9791009. https://doi.org/10.1007/s13524-016-0492-8 PMID:27383846

3. Biney AA. Exploring contraceptive knowledge and use among women experiencing induced abortion in the Greater Accra Region, Ghana. Afr J Reprod Health. 2011 Mar;15(1):37-46. PMID:21987936

4. Huang L, Sauve R, Birkett N, Fergusson D, van Walraven C. Maternal age and risk of stillbirth: a systematic review. CMAJ. 2008 Jan 15;178(2):165-72. https://doi.org/10.1503/cmaj.070150 PMID:18195290

5. Unsafe abortion: global and regional estimates of the incidence of unsafe abortion and associated mortality in 2008. 6th ed. Geneva: World Health Organization; 2011.

6. Daniel WW. Biostatistics, a foundation for analysis in the health sciences. 8th ed. Hoboken (NJ): John Wiley \& Sons, Inc.; 2005:186-90.

7. Department of Public Health. [Report on annual and monthly target population]. Mosul (Iraq): Nineveh Health Directorate; 2011. [In Arabic]

8. Chadha VK. Sample size determination in health studies. NTI Bull. 2006;42(3):55-62.

9. Carlson J, Tomkowiak J, Stilp C. Using the Angoff method to set defensible cut-off scores for standardized patient performance evaluations in PA education. J Physician Assist Educ. 2009;20(1):15-23.

10. Al-Youzbaki DhB. Cultural sociology for health and illness. Mosul: Mosul College of Medicine, University of Mosul; 2007.

11. Greenberg R, Daniels S, Flanders W, Eley J. Boring J. Medical epidemiology. 4th ed. New York McGraw-Hill; 2004.

12. Demirel S. Abortion from an Islamic ethical point of view. Int J Business Soc Sci. 2011 Jan;2(1):230-7.

13. Ministry of Iraqi Justice. The penal-code with amendments. 3rd ed. Baghdad: Al-Waqai' Al-'Iraqiya; 1980 (No. 2796). 
14. Berer M. Abortion law and policy around the world. Health Hum Rights, 2017 Jun; 19(1):13-27. PMID:28630538

15. International Household Survey Network. Syrian Arab Republic. Multiple indicator cluster survey 2006, monitoring the situation of children and women. Central Bureau of Statistics (http://catalog.ihsn.org/index.php/catalog/970, accessed 20 April 2018)

16. Roudi-Fahimi F, Dabash R. Abortion in the Middle East and North Africa. Washington D.C (USA): Population Reference Bureau; 2008.

17. Sedgh G., Bearak J, Singh S., Bankole A., Popinchalk A, Ganatra B, et. al. Abortion incidence between 1990 and 2014: global, regional, and subregional levels and trends. Lancet. 2016 Jul 16;388(10041):258-67. https://doi.org/10.1016/So140-6736(16)30380-4 PMID:27179755

18. Ganatra B, Gerdts C, Rossier C, Johnson BR Jr, Tunçalp Ö, Assifi A, et al. Global, regional, and subregional classification of abortions by safety, 2010-14: estimates from a Bayesian hierarchical model. Lancet. 2017 Nov 25;390(10110):2372-81. https://doi. org/10.1016/So140-673(17)31794-4. PMID:28964589

19. Al-Jawadi AA. Al-Bakry DhH. Determining levels and predictors of family planning unmet need in Mosul City, north of Iraq: a cross-sectional study. Middle East J Fam Med. 2010;8(4):10-6.

20. Al-Sammak NI, Al-Jawadi AA. Contraceptive use dynamics among married women attending primary health care centers in Mosul city, Iraq: A cross-sectional study. Middle East J Fam Med. 2012;10(1):29-34.

21. Iraq: Central Organization for Statistics and Information Technology, Kurdistan Regional Statistics Office, Ministry of Health, UNICEF; 2007 (Final report) (https://www.unicef.org/iraq/Iraq_2006_MICS_English.pdf, accessed 20 April 2018).

22. Erfani A, McQuillan K. Rates of induced abortion in Iran: the roles of contraceptive use and religiosity. Stud Fam Plann. 2008 Jun;39(2):111-22. https://doi.org/10.1111/j.1728-4465.2008.00158.x PMID:18678175

23. Sampling methods and sample size. In: Health research methodology: a guide for training in research methods. 2nd Ed. Manila: Regional Office for the Western Pacific;2001:71-8. 


\begin{tabular}{|c|c|c|c|c|c|c|}
\hline \multicolumn{3}{|c|}{ Stratification } & \multirow[t]{2}{*}{ Population size } & \multirow{2}{*}{$\begin{array}{c}\text { No. of married } \\
\text { women }(15-49) \\
\text { years }\end{array}$} & \multicolumn{2}{|c|}{ Weighted size } \\
\hline 1st & 2nd & $3 r d$ & & & $\begin{array}{l}\text { Proportional } \\
\text { sample size }\end{array}$ & $\begin{array}{l}\text { No. of studied } \\
\text { mothers }\end{array}$ \\
\hline \multirow{7}{*}{ North-west } & \multirow{3}{*}{ Urban } & Al-Yarmook & 56596 & 7923 & $5.8 \%$ & 76 \\
\hline & & & & & & \\
\hline & & Al-Hadbaa & 45900 & 6426 & $4.7 \%$ & 62 \\
\hline & \multirow{3}{*}{ Peri-urban } & Nablus & 68000 & 9520 & $6.9 \%$ & 89 \\
\hline & & & & & & \\
\hline & & Tamooz & 37707 & 5279 & $3.9 \%$ & 50 \\
\hline & Rural & Al-Mawali & 8400 & 1176 & $0.9 \%$ & 12 \\
\hline & Sub-total & & 216603 & 30324 & $22.2 \%$ & 289 \\
\hline \multirow{8}{*}{ South-west } & \multirow{3}{*}{ Urban } & Babel-Baidh & 255505 & 35771 & $26.1 \%$ & 340 \\
\hline & & & & & & \\
\hline & & Al-Qarbi & 32276 & 4519 & $3.3 \%$ & 43 \\
\hline & \multirow{3}{*}{ Peri-urban } & Al- Rafedeen & 40590 & 5683 & $4.1 \%$ & 53 \\
\hline & & & & & & \\
\hline & & Al-Ma'moon & 23924 & 3349 & $2.4 \%$ & 31 \\
\hline & Rural & Albu-Seef & 8000 & 1120 & $0.8 \%$ & 10 \\
\hline & Sub-total & & 360295 & 50442 & $36.7 \%$ & 477 \\
\hline \multirow{7}{*}{ North-east } & \multirow{3}{*}{ Urban } & Al-Arabi & 15015 & 2102 & $1.5 \%$ & 20 \\
\hline & & & & & & \\
\hline & & Al-Sukkar & 35035 & 4905 & $3.6 \%$ & 47 \\
\hline & \multirow{3}{*}{ Peri-urban } & Al-Rasheedia & 62563 & 8759 & $6.4 \%$ & 83 \\
\hline & & & & & & \\
\hline & & Al-Qahera & 29229 & 4092 & $3 \%$ & 39 \\
\hline & Rural & Sad-Badoosh & 1500 & 210 & $0.2 \%$ & 3 \\
\hline & Sub-total & & 143342 & 20068 & $14.7 \%$ & 191 \\
\hline \multirow{9}{*}{ South-east } & \multirow{3}{*}{ Urban } & Al-Noor & 60860 & 8520 & $6.2 \%$ & 81 \\
\hline & & & & & & \\
\hline & & Al-Wahda & 8412 & 1178 & $0.9 \%$ & 12 \\
\hline & \multirow{3}{*}{ Peri-urban } & Al-Zahraa & 44067 & 6169 & $4.5 \%$ & 59 \\
\hline & & & & & & \\
\hline & & Al-Karama & 122325 & 17126 & $12.5 \%$ & 163 \\
\hline & Rural & Al-Khadhraa & 23000 & 3220 & $2.3 \%$ & 30 \\
\hline & \multicolumn{2}{|l|}{ Sub-total } & 258664 & 36213 & $26.4 \%$ & 345 \\
\hline & \multicolumn{2}{|l|}{ Grand total } & 978904 & 137047 & $100.0 \%$ & 1302 \\
\hline
\end{tabular}

